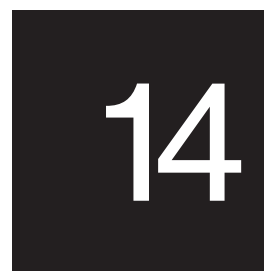

\title{
Tourism and culture: a sustainable partnership
}

\section{Levani V. Tuinabua}

In the Pacific, and certainly in Fiji, tourism has been stigmatised as the industry that trivialises sacred traditions, brings us drugs and immodesty and destroys culture. In instances where these have occurred tourism cannot, and should not, be held totally responsible for these changes as it is only one of numerous influences and forces that brought them about. It was not the sole factor. Indeed, when one takes a closer look at tourism, it is actually contributing to the preservation of culture.

Increasingly, tourists of today are shunning enclave holidays. These are holidays where they are whisked from the airport to a resort to hibernate for a week or so before they are whisked back to the airport for the journey home. Today's tourists want to see and get to know the country in which they are holidaying. They want to meet the people, eat what they eat, experience how they live, and get to know their culture.

Against this background, tourism destinations are developing new products to satisfy this demand. Even a regional organisation like the Tourism Council of the South Pacific has not been immune to this trend. Between 1989 and 1994, we were heavily involved in efforts to expand and diversify the products available to tourists in the South Pacific. 
In Fiji, we were involved in the development of the Tavuni Hill Fort near Sigatoka as a tourist attraction. One old man from a nearby village tells how the hill fort was founded. In the late eighteenth century, there was a dispute within the Tu'i Pelehake family in the village of Alaki in Mu'a, Tonga. A member of the family, Maile Latumai, decided to leave for Fiji and, during the trip, he saw Kadavu and Serua but did not go ashore. He did go ashore at Korotogo on the Coral Coast, and, after moving around a little, he finally settled at Tavuni. Today, Maile's descendants, called the Yavusa Noitoga, live in a number of villages around Tavuni Hill Fort.

The Tavuni Hill Fort is a cultural heritage site, representative of the links between Fiji and Tonga. This site was chosen not only because of its cultural attributes but also because it is close to the Queens Road and in a high-density tourism area. These factors will facilitate tourism and the commercial viability of the venture. Many of the historical and archaeological sites along the Sigatoka Valley have all but vanished due to agriculture or housing developments, but tourism has contributed to the preservation of the Tavuni Hill Fort.

Some time ago, a lad from Kabara or Fulaga (two islands of the Lau group renowned for carving) built a Fijian canoe, a drua, and sailed it to Suva intending to use it for short cruises in the harbour. The cruises were popular, but the tourist industry in Fiji was in one of its cyclical recessions and tourists were not coming to Fiji, let alone Suva, and the innovative venture folded. But it is another example of tourism's role in the preservation of culture.

Coupled with a desire to be more meaningfully involved in the tourism sector, the development of modern day tourism has resulted in the mushrooming of small, family-run and 'value for money' lodges. Through tourism establishments like these, the tourist has the rare opportunity to live our culture. He eats what we eat, does what we do-particularly for farmstays-and sleeps like we sleep. Last month, I attended the first ever Solomon Islands National Tourism Conference, which was followed immediately by an ecotourism conference. At tea one morning, I was delighted to hear a Solomon Island lady explaining with pride how she prepares local dishes for her tourists and how her guests devour them. In this case, tourism is contributing to the preservation of our culture. After all, food is an indispensable part of South Pacific culture.

Although Frank Hilton is reported to have said that the three most important factors for a hotel are: 'One, location; two, location; and 
three, location' tourism is not an industry constrained by the presence of infrastructure and utilities (although of course, it is tremendously beneficial if these facilities are available). This makes hotels and resorts a very mobile industry. They can be located throughout a country. Indeed, sometimes the more inaccessible a resort is, the more exclusive and expensive it gets-mainly because it can claim to provide privacy in these days of cameras with telephoto lenses! Because hotels are able to move, workers are not always forced to uproot themselves from the social and cultural environment in order to obtain employment in the tourism industry. This is one more way in which tourism supports the preservation of culture.

One eight-unit boutique resort off the coast of Vanua Levu does this and more. The management has employed two or three teams of neighbouring villagers. Each team is employed for two weeks or so before it is sent back to the village and a new team is engaged.

Through this approach there is an obvious distributional benefit as many more people are employed at the resort, and because each team is not permanently employed, the sociocultural dislocation is not so great.

A stretch of white sandy beach edged by swaying palm trees is no unique attribute. It looks the same whether it is in the Caribbean, Mauritius or in the South Pacific. Similarly for five star resorts, cruise ships, and colourful, romantically named yet deceptive cocktails. If you ask the tourism industry of the South Pacific, they will say that what sets the South Pacific apart from all the other tropical and maritime destinations are the South Pacific peoples and cultures. Where else in the world can one experience the captivating sways of a Tahitian tamure or the serenity and grace of a Tongan taualunga? Where else in the world can one experience the myriad of colours and costumes of traditional Papua New Guinean outfits? Where else in the world can one experience the raw challenge of a Pentecost dive or the pomp and precision of a Fijian yaqona ceremony? The examples go on and on.

These can only be experienced in the South Pacific. These are what set our region and peoples apart. In tourism, we call them our 'unique selling points'. Without them, we are no longer unique. Without them, we are like any other tropical holiday destination. The preservation of the region's culture means the maintenance of our unique selling points in the tourism industry. The preservation of our cultures is a prerequisite to a sustainable tourism industry in the region. 